\title{
ĐĂC ĐIỂM LÂM SÀNG VÀ HİNH ẢNH HỌC Ở BÊ̂NH NHÂN NHồI MÁU NÃO DIỆN RộNG BÁN CẦU Có ĐắT NộI KHÍ QUẢN
}

\section{TÓM TẮT}

Muc tiêu: Nhân xét một số đặc điểm lâm sàng, hình ảnh học ở bệnh nhân nhồi máu não diện rộng bán câu có đặt nội khí quản (NKQ). Đối tượng nghiên cứu: 31 bệnh nhân nhồi máu não diện rộng bán cầu có đặt NKQ் điều trị tại Trung tâm thần kinh Bệnh viện Bạch Mai từ tháng 8/2020-7/2021. Phương pháp nghiển cứu: Mô tả cắt ngang. Kết quả: Tuối trung bình của nhóm bệnh nhân nghiên cứu là $70,32 \pm 11,37$ tuổi, nam giới chiếm $67,7 \%$, tỷ lệ tử vong là $41,9 \%$. Các triệu chứng lâm sàng khi khởi phát thường gặp bao gồm: liệt vận động (100\%), rối loan ngôn ngữ (100\%), rối loạn ý thức $(90,3 \%)$, quay mắt quay đâu $(77,4 \%)$, rối loạn cơ tròn $(74,2 \%)$.

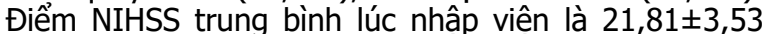
điểm, điểm Glasgow trung bình lúc nhập viện là $11,87 \pm 1,15$ điểm. Đăt nội khí quản do nguyên nhân thần kinh chiếm $80,6 \%$; điểm Glasgow trung bình lúc đă̆t NKQ là $9,10 \pm 1,35$ điểm; có $51,6 \%$ bênh nhân bất thường kích thước đồng tử và $35,5 \%$ bệnh nhân mất phản xa ánh sáng đồng tử lúc đăt NKQ. Điểm ASPECT trung bình lúc vào viện là 4,39 1 1,15 điểm; mức độ đè đẩy đường giữa trung bình là $7,03 \pm 3,83 \mathrm{~mm}$, trong đó có $22,6 \%$ bệnh nhân đè đẩy đường giữa độ 3 ( $>10 \mathrm{~mm})$; chuyển dang chảy máu chiếm $45,2 \%$. Kết luận: Bệnh nhân nhồi máu não diện rộng bán cầu có đă̆t NKQ là một dạng nặng của đột quỵ nhồi máu não với các đặc điểm lâm sàng và hình ảnh học đa dạng, mức độ tàn tật nặng và nguy cơ tử vong cao $(41,9 \%)$.

Tư khóa: Nhồi máu não diện rộng bán cầu, nội khí quản.

\section{SUMMARY}

\section{CLINICAL FEATURES AND IMAGES OF \\ PATIENTS WITH LARGE HEMISPHERIC INFARCTION WITH ENDOTRACHEAL INTUBATION}

Background: Comments on clinical features and images of patients with large hemispheric infarction with endotracheal intubation. Method: Study of 31 patients with the intubation, were treated in Neurological Center of Bach Mai Hospital from August 2020 to July 2021. Result: The average age of patients was $70.32 \pm 11.37$, the percentage of male was $67.7 \%$, mortality rate was $41,9 \%$. Frequent clinical symptoms onset included: paralysis (100\%),

\footnotetext{
${ }^{1}$ Bênh viên Bach Mai

2Trường Đại học Y Hà Nọi

33ệnh Viện Đa khoa Của Đông

Chịu trách nhiệm chính: Võ Hồng Khôi

Email: drvohongkhoi@yahoo.com.vn

Ngày nhận bài: 7.9.2021

Ngày phản biện khoa học: 25.10.2021

Ngày duyệt bài: 9.11.2021
}

\section{Võ Hồng Khôi ${ }^{1,2}$, Nguyễn Văn Quân ${ }^{3}$}

language disorder (100\%), consciousness disorder $(90.3 \%)$, head-eye deviation $(77.4 \%)$, urinary and fecal incontinence $(74.2 \%)$. The mean of NIHSS score and Glasgow score at hospital admission was $21.81 \pm 3.53$ and $11,87 \pm 1,15$, resepectively. The intubation due to neurologic disorders accounted for $80.6 \%$, the mean of Glasgow score in case of intubation was $9.10 \pm 1.35 ; 51.6 \%$ patients with abnormal pupil size and $35.5 \%$ patients with loss of light reflex when intubated. The ASPECT score at hospital admission was 4.39 \pm 1.15 ; average midline shift classification was $7.03 \pm 3.83 \mathrm{~mm}$ including $22.6 \%$ patients with midline shift classification level 3 $(>10 \mathrm{~mm}) . \quad 45.2 \%$ patients with hemorrhagic transformation. Conclusion: Large hemispherical infarction is a severe form of stroke with various clinical features and images and high mortality rate $(41.9 \%)$

Keywords: Large hemispheric infaection, endotracheal intubation.

\section{I. ĐẶT VẤN ĐỀ}

Đột quy. não là nguyên nhân tử vong đứng hàng thứ ba và tàn phế đứng hàng thứ nhất. Các bệnh nhân đột quy. càng nặng càng làm tăng nguy cơ tử vong cũng như mức độ tàn phế. Nhồi máu não diện rộng bán câuu là một dạng nặng của đột quỵ nhồi máu não với diện tổn thướng lớn, lâm sàng thường nặng nề, có thể kèm theo rối loạn ý thức, mất khả năng bảo vệ đường thở, ùn tắc đờm dãi, hoặc có thể suy hổ hấp do ảnh hưởng trung khu hô hấp hay do biến chứng viêm phổi. Việc đặt nội khí quản trong quá trình điều trị cho những bệnh nhân này là cân thiết để hỗ trợ hô hấp, bảo vệ đường thở, đảm bảo cung cấp oxy đây đủ cho tế bào não, góp phân chống phù não. Mặc dù tỉ lệ bệnh nhân nhồi máu não phải đặt nội khí quản không cao (10-16\%) nhưng tiên lượng lại rất xấu, di chứng thân kinh nặng nề, tỷ lệ tử vong cao $(40-70 \%)^{1}$. Tại Việt Nam, đã có nhiều nghiên cứu về bệnh nhân nhồi máu não nói chung nhưng còn ít nghiên cứu vê bệnh nhân nhồi máu não diện rộng bán câu có đặt NKQ. Vì vậy, chúng tôi tiến hành nghiên cứu để tài với mục tiêu: "Nhận xét một số đặc điểm lâm sàng, hình ảnh học ở bệnh nhân nhồi máu não diện rộng bán cầu có đặt nội khí quản".

\section{II. ĐỐI TƯỢNG VÀ PHƯƠNG PHÁP NGHIÊN CỨU 2.1 Đối tượng nghiên cứu}

- Các bệnh nhân được chẩn đoán nhồi máu não diện rộng bán câu được đặt NKQ điều trị tại Trung tâm thân kinh - Bệnh viện Bạch Mai từ 8/2020-7/2021. 
- Tiêu chuẩn chọn bệnh nhân:

+ Được chẩn đoán xác định nhồi máu não:

- Lâm sàng (theo đinh nghĩa đột quy não của Tổ chức Y tế Thế giới 1990).

- Hình ảnh học: có hình ảnh nhồi máu não tương ứng trên CLVT/CHT.

+ Hình ảnh tổn thương nhồi máu não diện rộng trên CLVT/CHT: ASPECT < 6 điểm và có ít nhất một tổn thương hạch nền.

- Tiểu chuẩn loại trừ: tiền sử đột quỵ não có mRS > 2 điểm hay có các bệnh lý nội khoa nặng như suy gan, suy thân nặng, ung thư', COPD...

\subsection{Phương pháp nghiên cứu}

- Thiết kế nghiên cứu: Nghiên cứu mô tả cắt ngang

- Tất cả các bênh nhân khám thấy các dấu hiệu của đột quỵ não nghi ngờ nhồi máu não diện rộng bán cầu, được chụp CT Scaner hoặc MRI so não để chẩn đoán xác định, sau đó được khai thác các triêu chứng lâm sàng và hình ảnh học theo một mấu bệnh án thống nhất.

- Nôi dung nghiên cứu: Nhận xét một số đặc điểm chung, đặc điểm lâm sàng, hình ảnh học ở bệnh nhân nhồi máu não diện rộng bán cầu có đặt NKQ.

- Xử lý số liệu: theo phương pháp thống kê y học, sử dụng phần mềm SPSS 20.0

\section{KẾT QUẢ NGHIÊN CỨU}

\section{1 Đặc điểm chung nhóm nghiên cứu \\ Bảng 3.1 Đặc điểm chung nhóm nghiên} cứu

\begin{tabular}{|c|c|c|c|}
\hline \multicolumn{2}{|c|}{ Đặc điếm chung } & Số BN & Tỷ lệ \% \\
\hline \multirow{2}{*}{ Giới } & Nam & 21 & $67,7 \%$ \\
\cline { 2 - 4 } & Nữ & 10 & $32,3 \%$ \\
\hline \multicolumn{2}{|c|}{ Tuối trung bình (năm) } & \multicolumn{2}{|c|}{$70,32 \pm 11,37$} \\
\hline
\end{tabular}

Nhận xét: Tuổi trung bình ở nhóm bệnh nhân có đặt NKQ là 70,32 $\pm 11,37$ tuổi. Nam giới chiếm $67,7 \%$.

3.2 Một số đặc điểm lâm sàng nhóm nghiên cứu

Bảng 3.2 Một số tiền sử và yêu tố nguy cơ nhóm bệnh nhân nghiên cứu

\begin{tabular}{|l|l|l|}
\hline Tiền sử và yếu tố nguy cơ Số BN Tỷ lệ \% \\
\hline
\end{tabular}

\begin{tabular}{|c|c|c|}
\hline Tăng huyết áp & 18 & $58,1 \%$ \\
\hline Rung nhĩ & 5 & $16,1 \%$ \\
\hline Đái tháo đường & 8 & $25,8 \%$ \\
\hline Đột quy não cũ & 6 & $19,4 \%$ \\
\hline Rối loạn lipid máu & 2 & $6,5 \%$ \\
\hline Hút thuốc lá & 5 & $16,1 \%$ \\
\hline
\end{tabular}

Nhân xét: Tiền sử và yếu tố nguy cơ thường gặp là: Tăng huyết áp $(58,1 \%)$, đái tháo đường $(25,8 \%)$, đột quy. não cũ $(19,4 \%)$, rung nhî $(16,1 \%)$.
Bảng 3.3 Một số đặc điểm lâm sàng nhóm bệnh nhân nghiên cứu

\begin{tabular}{|c|c|c|}
\hline Đặc điểm lâm sàng & Số BN & Tỷ lệ \% \\
\hline Đau đâu khi khởi phát & 15 & $48,1 \%$ \\
\hline RL ý thức khi khởi phát & 28 & $90,3 \%$ \\
\hline RL ngôn ngữ khi khởi phát & 31 & $100 \%$ \\
\hline Liệt vận động khi khởi phát & 31 & $100 \%$ \\
\hline RL cớ tròn khi khởi phát & 23 & $74,2 \%$ \\
\hline Quay mắt quay đầu & 24 & $77,4 \%$ \\
\hline Điếm Glasgow lúc vào viện & $11,87 \pm 1,15$ \\
\hline Diếm NIHSS lúc vào viện & $21,81 \pm 3,53$ \\
\hline $\begin{array}{c}\text { Sức cớ trung } \\
\text { bình lúc vào } \\
\text { viện }\end{array}$ & Sức cơ chân & \multicolumn{2}{|c|}{$0,39 \pm 0,67$} \\
\cline { 2 - 3 } & Sức cơ tay & \multicolumn{2}{|c|}{$0,23 \pm 0,50$} \\
\hline
\end{tabular}

Nhận xét: Triệu chứng lâm sàng lúc khởi phát của nhóm bểnh nhân nghiên cứu rất đa dạng, các triệu chứng thường gặp lúc khởi phát bao gồm: Liệt vận động $(100 \%)$, rối loạn ngôn ngữ $(100 \%)$, rối loạn ý thức $(90,3 \%)$, rối loạn cơ tròn $(74,2 \%)$. Điểm Glasgow trung bình lúc vào

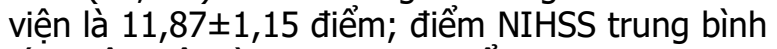
lúc nhập viện là $21,81 \pm 3,53$ điểm.

Bảng 3.4 Các đặc điểm lâm sàng liên quan đến đặt NKQ

\begin{tabular}{|c|c|c|c|}
\hline \multicolumn{2}{|c|}{$\begin{array}{l}\text { Đặc điếm lâm sàng liên } \\
\text { quan đến đặt NKQ }\end{array}$} & $\begin{array}{l}\text { Số } \\
\text { BN }\end{array}$ & $\begin{array}{l}\text { Tỷ lệ } \\
\%\end{array}$ \\
\hline \multirow{2}{*}{$\begin{array}{l}\text { Nguyên nhân } \\
\text { đặt NKQ }\end{array}$} & $\begin{array}{l}\text { Nguyên nhân } \\
\text { thần kinh }\end{array}$ & 25 & $80,6 \%$ \\
\hline & $\begin{array}{l}\text { Nguyên nhân } \\
\text { hô hấp }\end{array}$ & 6 & $19,4 \%$ \\
\hline \multicolumn{2}{|c|}{ Thời điểm đặt NKQ (ngày) } & \multicolumn{2}{|c|}{$2,77 \pm 1,41$} \\
\hline \multirow{2}{*}{\multicolumn{2}{|c|}{ Điếm Glasgow lúc đă̆t NKQ }} & \multicolumn{2}{|c|}{$9,10 \pm 1,35$} \\
\hline & & 16 & $51,6 \%$ \\
\hline \multicolumn{2}{|c|}{$\begin{array}{l}\text { Bất thường kích thước đồng tư } \\
\text { Mất phản xa ánh sáng đôna tư }\end{array}$} & 11 & $35,5 \%$ \\
\hline
\end{tabular}

Nhân xét: Lý do đặt NKQ ở nhóm nghiên cứu phần lớn do nguyên nhân thần kinh: 80,6\%. Thời điểm đặt NKQ trung bình là $2,77 \pm 1,41$ ngày, điểm Glasgow lúc đặt NKQ trung bình $9,10 \pm 1,35$ điểm.

\section{Điểm Glasgow khi đặt NKQ} $6.5,7 \%$

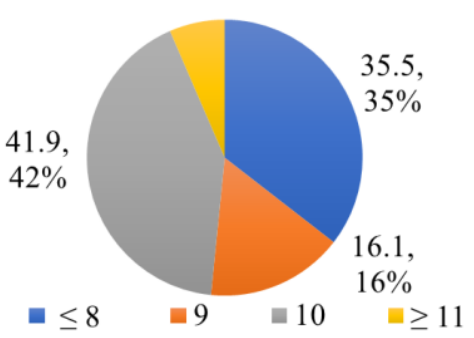

Biểu đồ 3.1. Phân loại điểm Glasgow khi dăt NKQ

Nhận xét: Có 35,5\% bệnh nhân đặt NKQ với Glasgow $\leq 8$ điểm, Glasgow $\geq 11$ điểm là $6,5 \%$. 
3.3 Một số đặc điểm hình ảnh học nhóm bệnh nhẩn nghiển cứu

Bảng 3.5 Đặc điểm hình ảnh học nhóm nghiên cứu

\begin{tabular}{|c|c|c|c|}
\hline \multicolumn{2}{|c|}{ Đặc điểm hình ảnh học } & $\begin{array}{c}\text { Số bệnh } \\
\text { nhâ̂n }\end{array}$ & $\begin{array}{c}\text { Tỷ lệ } \\
\text { (\%) }\end{array}$ \\
\hline \multirow{2}{*}{$\begin{array}{c}\text { Chuyển dạng } \\
\text { chảy máu }\end{array}$} & Kó & 14 & $45,2 \%$ \\
\hline Điếm ASPECT trung bình & 17 & $54,8 \%$ \\
\hline \multicolumn{2}{|c|}{$4,39 \pm 1,15$} \\
\hline Mức độ di lệch đường giữa & \multicolumn{2}{|c|}{$7,03 \pm 3,83$} \\
\hline
\end{tabular}

Nhận xét: Điểm ASPECT trung bình lúc nhập viện là $4,39 \pm 1,15$ điểm. Mức độ di lệch đường giữa là 7,03 $\pm 3,83 \mathrm{~mm}$. Có $45,2 \%$ bệnh nhân có chuyển dạng chảy máu.

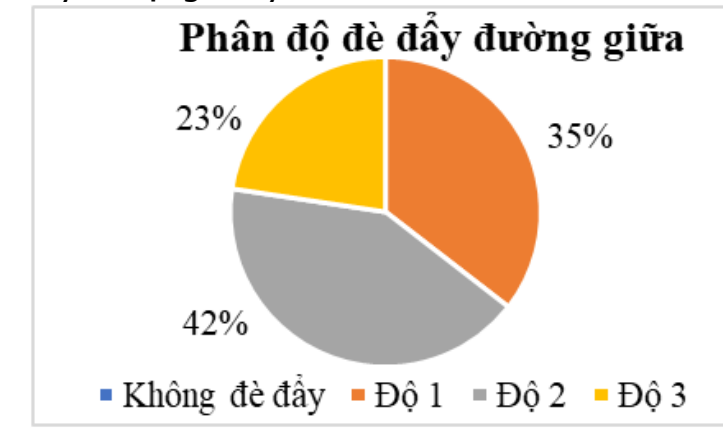

Biểu đồ 3.2 Phân độ đè đây đường giữa nhóm bênh nhân nghiên cứu

Nhân xét: Tất cả bênh nhân nghiên cứu đều có đè đẩy đường giữa ở các mức độ khác nhau, trong đó độ 1 là $35,5 \%$, độ 2 là $41,9 \%$, độ 3 là $22,6 \%$.

3.4 Kết quả điêu trị nhóm bệnh nhân nghiên cứu

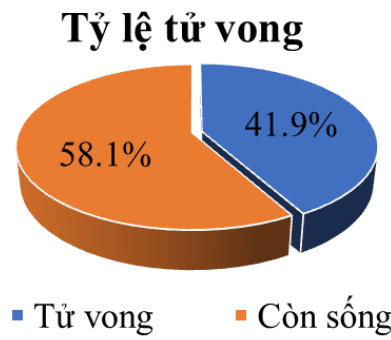

Biểu đồ 3.3 Kêt quả điều trị ở nhóm bệnh nhân nghiên cứu

Nhận xét: Tỷ lệ tử vong ở nhóm bệnh nhân có đặt NKQ còn cao: 41,9\%.

\section{BÀN LUẬN}

Tuổi trung bình ở nhóm bệnh nhân nghiên cứu là 70,32 11,37 tuổi, cao hớn kết quả nghiên cứu của Vũ Anh Nhị và Trần Thanh Hùng $(61,5 \pm 13,4 \text { tuổi })^{2}$ và nghiên cứu của Berrouschot và cộng sự $(63 \pm 13)^{3}$. Nam giới chiếm $67,7 \%$ thấp hơn nghiên cứu của Nguyễn Hồng Quân
$(73,2 \%)^{4}$. Tỷ lệ tử vong ở nhóm bệnh nhân có đặt NKQ là 41,9\%, kết quả này tương tự một số kểt quả nghiên cứu như của Francois Santoli và cộng sự ( $40,5 \%$ bệnh nhân tử vong trong tuần đầu tiên khi nhập viện, $72,4 \%$ bệnh nhân tử vong sau 1 năm) $)^{5}$, Nguyễn Hồng Quân (tỉ lệ tử vong là $42,6 \%)^{4}$.

Triệu chứng lâm sàng ở nhóm bệnh nhân nghiên cứu rất đa dạng, các triệu chứng lâm sàng lúc khởi phát thường gặp bao gồm: liệt vận động $(100 \%)$, rối loạn ngôn ngữ (100\%), rối loạn ý thức $(90,3 \%)$, quay mắt quay đầu $(77,4 \%)$ và rối loạn cơ tròn $(74,2 \%)$. Điểm Glasgow trung bình lúc nhập viện là $11,87 \pm 1,15$ điểm; điểm NIHSS trung bình lúc nhập viện là

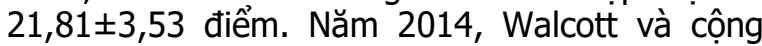
sự nghiên cứu 46 bệnh nhân nhồi máu não động mạch não giữa nghiêm trọng thấy điểm Glasgow lúc vào viện là $10,7 \pm 0,4$ điểm, điểm NIHSS lúc vào viện là $20,9 \pm 0,5$ điểm ${ }^{6}$.

Chỉ định đặt NKQ do nguyên nhân thần kinh chiếm $80,6 \%$, kết quả này tương tự kết quả nghiên cứu của Eva Schielke và cộng sự $(81 \%)^{7}$, cao hơn kết quả nghiên cứu của Nguyển Hồng Quân $(76 \%)^{4}$. Điểm Glasgow trung bình lúc đặt NKQ là $9,10 \pm 1,35$ điểm, trong đó Glasgow $\leq 8$ điểm là $35,5 \%$, Glasgow $\geq 11$ điểm là $6,5 \%$. Kết quả này cao hơn nghiên cứu của Nguyễn Hồng Quân (điểm Glasgow trung bình khi đặt NKQ là $7,9 \pm 2,3$ điểm $)^{4}$. Tại thời điểm đặt NKQ, có $51,6 \%$ bệnh nhân bất thường kích thước đồng tử và 35,5\% bệnh nhân mất PXAS đồng tử.

Điểm ASPECT trung bình lúc nhập viện ở

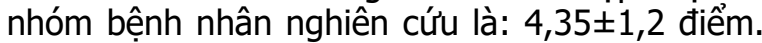
Mức độ di lệch đường giữa trung bình là $7,03 \pm 3,83 \mathrm{~mm}$, trong đó di lệch đường giữa độ 1 là $35,5 \%$, độ 2 là $41,9 \%$ và độ 3 là 22,6\%. Nguyễn Thị Oanh (2018) nghiên cứu bệnh nhân nhồi máu não trên lều tiểu não có thông khí cơ học nhận thấy đè đẩy đường giữa trung bình là $10,04 \pm 4,69 \mathrm{~mm}^{8}$. Mayer và cộng sự (1996) nghiên cứu các bệnh nhân đột quy có đặt NKQ nhận thây có $30 \%$ bệnh nhần đè đây đường giữa độ $3^{9}$. Nghiên cứu của chúng tôi cũng nhận thấy chuyển dạng chảy máu trên hình ảnh học chiếm 45,2\%.

\section{KẾT LUẬN}

Bệnh nhân nhồi máu não diện rộng bán câu có đặt NKQ là một dạng nặng của đột quy nhồi máu não với các đặc điểm lâm sàng và hình ảnh học đa dạng, nguy cơ tử vong cao (41,9\%).

TÀI LIỆU THAM KHẢO

1. Gupta $P$, Prasad $K$, Kumar $A$, Kumar $P$, Bhatia 
R, Tripathi M. Clinical predictors and outcome of patients of acute stroke requiring ventilatory support: A prospective hospital based cohort study. Journal of the Neurological Sciences. 2014;337(1-2):14-17.

2. Vũ Anh Nhị, Trân Thanh Hùng (2012), "Kiểm định các yếu tố tiên lượng đột quy cấp có đă̆t nội khí quản", Tap chí Y dược lâm sàng 108, 7 (số đặc biệt), tr. 267-270.

3. Berrouschot J, Rössler A, Köster J, Schneider D. Mechanical ventilation in patients with hemispheric ischemic stroke: Critical Care Medicine. 2000;28(8):2956-2961.

4. Nguyễn Hồng Quân, Nguyễn Văn Thông (2012), "Nghiển cứu đắc điểm lâm sàng và môtt số yếu tố tiên lượng bênh nhân đột quy có đặt nội khí quản", Tap chí Y dược lâm sàng 108 , số 7(Số đặc biệt), tr. 234 - 240.
5. Santoli F, De Jonghe B, Hayon J, et al. Mechanical ventilation in patients with acute ischemic stroke: survival and outcome at one year. Intensive Care Med. 2001;27(7):1141-1146.

6. Walcott BP, Miller JC, Kwon C-S, et al. Outcomes in Severe Middle Cerebral Artery Ischemic Stroke. Neurocrit Care. 2014;21(1):20-26.

7. Schielke E, Busch MA, Hildenhagen $T$, et al Functional, cognitive and emotional long-term outcome of patients with ischemic stroke requiring mechanical ventilation. J Neurol. 2005;252(6):648-654.

8. Trân Thị Oanh (2018). Nghiên cứu đăc điểm lâm sàng, cận lâm sàng và một số yếu tố liền quan của bệnh nhân nhồi máu não cấp trên lều tiểu não có thông khí cơ hoc. :27.

9. Mayer SA, Copeland D, Bernardini GL, et al. Cost and Outcome of Mechanical Ventilation for LifeThreatening Stroke. Stroke. 2000;31(10): 2346-2353.

\section{ĐÁNH GIÁ KẾT QUẢ ĐIỀU TRI DUY TRÌ DOCETAXEL TRÊN BÊ̂NH NHÂN UNG THƯ PHỔI KHÔNG TẾ BÀO NHỎ GIAI ĐOẠN MUộN TẠI BỆNH VIỆN UNG BƯỚU NGHỆ AN}

\section{Nguyễn Quang Trung*, Phạm Vĩnh Hùng*, Nguyễn Viết Bình*, Nguyễn Khánh Toàn*, Phạm Thị Hường \\ DOCETAXEL IN ADVANCED STAGE NON SMALL CELL LUNG CANCER AT NGHE AN ONCOLOGY HOSPITAL}

\section{TÓM TẮT}

Mục tiêu: Đánh giá hiệu quả, độc tính của phác đồ Docetaxel duy trì trên bệnh nhần ung thư phối không tế bào nhỏ giai đoạn muộn tại BVUBNA. Đối tượng và phương pháp nghiên cứu: Nghiên cứu hồi tiển cứu trên 47 bênh nhân ung thư phổi không tế bào nhỏ giai đoan muộđươợc điều trị duy trì Docetaxel sau khi điêu trị bước 1 bằng phác đồ hóa trị bộ đôi đạt đáp ứng hoăc bênh ổn đinh tai Bênh viên Ung bướu Nghệ An từ tháng 1/2016 đển tháng 8/2020. Kết quả: Tuổi TB của nhóm nghiên cứu là 62,5 $\pm 7,06$; Tỷ lế nam/ nữ $3,7 / 1$. Có $1 B N$ đáp ứng hoàn toàn $(2,3 \%)$; $34 \%$ đáp ứng 1 phần; $38,3 \%$ bênh ổn đinh. Thời gian sống thêm không tiến triển $9.0 \pm 0.4$ tháng, thời gian sống thêm toàn bộ 18,7 tháng. Các tác dụng không mong muốn: Giảm huyết sắc tổ $78.7 \%$, giảm bạch câu là $46.7 \%$, giảm bach câu có sốt là $17,1 \%$ trong đó $4.3 \%$ ở độ 3. Tăng men gan (21,3\%), Nôn và buồn nôn $(27.6 \%)$. Hầu hết ở độ 1- 2 . Kết luận: Điều trị Docetaxel duy trì cho hiệu quả cao và dung nạp thuốc tốt ở bênh nhân UTPKTBN giai đoan muôn

Từ khóa: Ung thư phổi khônng tế bào nhỏ giai đoạn muộn, Docetaxel duy trì

\section{SUMMARY}

\section{THE EFFICALLY OF MAINTANCE}

*Bệnh Viện Ung Bướu Nghê An

Chịu trách nhiệm chính: Phạm Thị Hường

Email: Bshuongn2ub@gmail.com

Ngày nhận bài: 8.9.2021

Ngày phản biên khoa hoc: 27.10.2021

Ngày duyệt bài: 11.11.2021
Objective: Effect and side effect of maintance Docetaxel in advance stage non-small cell lung cancer. Patients and method of study: Retrospective and prospective study on 47 non-small cell lung cancer patients in advanced stage after first- line treatmentdouble- platinum chemotherapy from January 2016 to August 2020. Results: Median of age $62,5 \pm 7,06$; Male/Female:3,7/1. A patient completely responded $(2,3 \%), 34 \%$ partial respone, stable disease rate $38,3 \%$. Mean Progression free survival $9.0 \pm 0.4$ months, overal survival 18,7 months. Side effects: anemia $78,7 \%$, neutropenia $46,7 \%$, transaminase elevation $21,3 \%$, nausea and vomiting $(27,6 \%)$. Almost side effects are grade $1-2$.

Key word: Advance stage Non small cell lung cancer, Maintance docetaxel.

\section{I. ĐĂT VẤN ĐỀ}

Ung thư phổi (UTP) là bệnh lý ác tính và là nguyên nhân gây tử vong do ung thư thường gặp nhất trên toàn cầu. Theo thống kê của Tồ chức nghiên cứu ung thư quốc tế IARC (Globocan 2018), ước tính có khoảng 2,1 triệu ca UTP mới mắc, chiếm $11,6 \%$ tổng số bệnh nhân ung thư và 1,8 triêu người tử vong, chiếm 18,4 $\%$ tổng số ca tử vong do ung thư nói chung [1]. Tại Việt Nam, các kết quả ghi nhận ung thư quần thể cũng cho thấy UTP có tỷ lệ mắc và tử vong cao ở cả hai giới[2]. Theo phân loại của Tổ chức 